\title{
Implementation of a cooling system to develop experimental fatigue tests below zero grades Celsius
}

\author{
Implementación de un sistema de enfriamiento para desarrollar pruebas de fatiga por debajo \\ de cero grados Celsius
}

\author{
C. G. Cárdenas-Arias ; C. L. Sandoval-Rodríguez ; ; A. D. Rincón-Quintero iD ; P. D. Díaz-Melo iD \\ DOI: https://doi.org/10.22517/23447214.23641 \\ Artículo de investigación científica y tecnológica
}

\begin{abstract}
Temperature is one of the matter properties with the greatest influence on the materials behavior existing in nature and those man designed. This physical magnitude allows to demonstrate and define behaviors and materials characteristics in the industry in general. Its influence is present in all the places where the materials fulfill functions, however, in some applications its influence is very little, which allows to disregard its effects.

In the steels case (one of the most used materials at the industrial level today), the temperature variation produces dilation or contraction, depending on the temperature magnitude and its variation that affects them. Temperature increases generate an expansion phenomenon in the materials, which under load will reach a point where they present thermal fatigue failure. The opposite is that of temperature drops, where the phenomenon that occurs is contraction, often leading to the loss of adjustments and interference that compromise the equipment functionality and integrity. The fatigue failure mentioned is presented as a result of the stresses and deformations present in both cases. It is desired to condition a rotational flex fatigue test equipment with a cooling system to bring the sample material to temperatures below zero degrees Celsius, in order to check how low temperatures, affect the resistance of steel to fatigue. For this, a cooling system was designed and the fatigue equipment was adapted to reduce heat transfer. After carrying out this implementation and determining that the sizes of the devices were suitable for the proposed purposes, the initial temperature tests were carried out and, once this part was achieved, three repetitions of a rotary fatigue test were performed that demonstrated that the equipment can operate normally.
\end{abstract}

Index terms - Cooling system, Fatigue, Fracture, Low temperature, Refrigeration.

This manuscript was sent on November 28, 2019 and accepted on November 23,2020

This work was supported by the Antonio Nariño University, Bucaramanga headquarters, the DIMAT (Diseño y Materiales) and GISEAC (sistemas de energía automatización y control) Research groups, of the Unidades Tecnológicas de Santander (UTS).

C. G. Cárdenas-Arias, is a researcher of the DIMAT group of the UTS (email: ccardenas@correo.uts.edu.co), in Calle de los Estudiantes \#9-82 Ciudadela Real de Minas-Bucaramanga.
Resumen - La temperatura es una de las propiedades de la materia con mayor influencia en el comportamiento de los materiales existentes en la naturaleza y aquellos diseñados por el hombre. Esta magnitud física permite demostrar $y$ definir comportamientos y características de los materiales en la industria en general. Su influencia está presente en todos los lugares donde los materiales cumplen funciones, sin embargo, en algunas aplicaciones su influencia es muy pequeña, lo que permite ignorar sus efectos. En el caso de los aceros (uno de los materiales más utilizados a nivel industrial en la actualidad), la variación de temperatura produce dilatación o contracción, dependiendo de la magnitud de la temperatura y la variación que los afecta. Los aumentos de temperatura generan un fenómeno de expansión en los materiales, que bajo carga alcanzarán un punto donde presentan fallas por fatiga térmica. Lo opuesto es el de las caídas de temperatura, donde el fenómeno que ocurre es la contracción, que a menudo conduce a la pérdida de ajustes e interferencias que comprometen la funcionalidad $e$ integridad del equipo. La falla por fatiga mencionada se presenta como resultado de las tensiones y deformaciones presentes en ambos casos. Se desea acondicionar un equipo de ensayo de fatiga por flexión rotativa con un sistema de enfriamiento para llevar el material de la muestra a temperaturas inferiores a cero grados Celsius, a fin de verificar cómo las bajas temperaturas afectan la resistencia del acero a fatiga. Para esto, se diseñó un sistema de enfriamiento y el equipo de fatiga se adaptó para reducir la transferencia de calor. Después de llevar a cabo esta implementación y determinar que los tamaños de los dispositivos eran adecuados para los propósitos propuestos, se realizaron las pruebas de temperatura iniciales $y$, una vez que se logró esta parte, se realizaron tres repeticiones de una prueba de fatiga rotativa que demostraron que el equipo puede operar normalmente.

Palabras clave- Baja temperatura, Fatiga, Fractura, Refrigeración, Sistema de enfriamiento

C. L. Sandoval-Rodríguez, is a researcher and leader of the GISEAC group, of the UTS (email: csandoval@ correo.uts.edu.co).

A. D. Rincón-Quintero, is a researcher of the DIMAT group of the UTS (arincon@ correo.uts.edu.co).

P. D. Díaz-Melo was linked to the Antonio Nariño University

The participation in the development of the adaptation is appreciated to the engineer Colmenares R Alexander. 


\section{INTRODUCTION}

$\mathrm{F}$ ATIGUE is the leading cause of structural damage in the industry. To understand this phenomenon, test equipment has been developed, mainly for rotary work[1].

The development of a rotational flexion fatigue equipment adaptation to perform tests at low temperature is presented, where a climatic chamber of cooling was designed so that temperatures below zero degrees Celsius can be reached, thus expanding the experimental capacities materials laboratory.

This work will allow new and better research in the area of materials fatigue and fracture, under low temperature conditions, which will undoubtedly correspond to a great novelty and will be very useful in characterizing the materials behavior at these operation conditions.

In industry, hostile environments are generally more common due to high temperatures. For this reason, the studies carried out over time, the latest technologies and advances in science, allow us to have a broad knowledge about the materials behavior materials in these conditions.

However, certain applications require performance in low temperature conditions[2]; such is the aerospace case and machinery applications operating in Arctic places. In aerospace applications, such as in aviation, low temperatures are due to the atmospheric effects presented at high altitudes when airplanes reach their cruising speed.

This questioning is what sets the project objective, which seeks to create an environment that allows testing materials from $0{ }^{\circ}$ to $-6^{\circ}$ Celsius temperature, since the theory indicates that fatigue resistance is affected at these temperatures. [3]

A cooling system aims to reduce the temperature of the defined space (which will be called control volume); for this, a series of equipment is required that exerts a cycle such that heat from the control volume is subtracted outwards. For this, external work is required since, as a consequence of the second thermodynamics law, energy moves naturally from a greater point to temperature lower and in the opposite case (such as cooling systems ), external work is required.

In quantitative terms, the equipment performance is measured by the coefficient of performance (COP), defined for refrigerators as: [4]

$$
\text { COP }=\frac{\text { Calor removido }}{\text { Trabajo requerido }}=\frac{Q_{L}}{W_{\text {neto }}}
$$

Many problems associated with the Carnot inverted cycle can be avoided by completely evaporating the refrigerant in the evaporator, so that only steam reaches the compressor and, on the other hand, replacing the expansion turbine with a throttle valve or capillary tube.[4]

\section{WORK DEVELOPMENT}

To work develop, some design parameters are proposed, then the elements selection to condition the camera is made, then the system was implemented and finally the installation was validated.

\section{A. Design parameters}

Cooled mass: corresponds to the cooling load that the system must carry out, in this case it corresponds to the total mass available inside the refrigerated chamber, within which the system specimen must be included. This whole mass is considered because a temperature steady state must be ensured, so all the mass inside the chamber must be at the same temperature.

The refrigerant to be used will be R134a Dupont brand, for its wide use in conventional refrigeration systems, which makes it a good alternative, easy to get. [5]

The temperature ranges will be a maximum of $28^{\circ} \mathrm{C}$ to $-6^{\circ} \mathrm{C}$, in this way the required temperature differential to be applied by cooling system is defined. On the other hand, environmental conditions will be typical in the Bucaramanga city.

\section{B. Item selection}

It starts from the mass that is in the chamber to be cooled, considering that the entire mass must be at the same temperature, which allows to guarantee a steady state of temperature for the performance of fatigue tests. A mass of 10 $[\mathrm{Kg}]$ is considered where the specimen and the supports of the machine are included. The specific heat corresponds to that of steel at room temperature. [6] Then have to remove the heat is given by:

$$
Q=m_{\text {acero }} * C_{p} * \Delta T
$$

The temperature differential is given from the objectives approach as follows:

$$
\Delta T=28-(-6)=34{ }^{\circ} \mathrm{C}
$$

Now, to consider the thermal load corresponding to the exchange with the surroundings, this will be taken as a percentage of the removed heat. This is valid for a properly insulated space, as reported, [7] since this exchange is very little compared to the heat to be removed, a value of $5 \%$ of the removed load will be taken as the loss value, according to [8] so the removed heat is:

$$
Q_{\text {remover }}=1.05 * Q=155.1[K J]
$$

The compressor function is to increase the refrigerant pressure, due to the way it operates, it is reasonable apply the steady-state model. [8] By the conservation of mass: [8]

Which leads to:

$$
m_{1}=m_{2}
$$

$$
V_{1} v_{1}=V_{2} v_{2}
$$


Being $m$ the mass flow, $V$ the volumetric flow and $v$ the specific volume of the refrigerant at the compressor inlets and outlets.

The compressor implies a work external to the system which is given by that change of enthalpy as:

$$
W_{i n}=m \cdot\left(h_{2}-h_{1}\right)
$$

According to [4] initial pressure values that can work are 15 [psi] and 130 [psi] in low and high respectively.

Using energy balance, the remove evaporator heat is given by

$$
Q_{L}=m \cdot\left(h_{2}-h_{1}\right)
$$

The exchange between the air in the chamber of the refrigerated space and the evaporator occurs by convection, [9]

$$
Q=h * A_{s}\left(T_{\text {aire }}-T_{R e f r}\right)
$$

Where, $A_{s}$ is the surface area of heat exchange, $h$ is the convection transfer coefficient, $T_{\text {aire }}$ and $T_{\text {Refr }}$ are, respectively, the air temperature in the refrigerated space and the coolant temperature.

From the Rodriguez \& Rueda work, [7] inside to the refrigerated chamber:

$$
h=52.34\left[W / m^{2} K\right]
$$

Using heat to be removed, the convective coefficient, the desired temperature and the ambient temperature (ie $\Delta \mathrm{T}$ ), the minimum area for the evaporator is:

$$
A_{\text {evap }}=0.083\left[\mathrm{~m}^{2}\right]
$$

The heat removal rate inside the refrigerated chamber is:

$$
Q_{L}=0.375[\mathrm{KJ} / \mathrm{s}]
$$

Assuming that the refrigerant comes out of the evaporator as saturated steam, it is necessary to: $h(P)=\left\{h_{1}=234[\mathrm{KJKg}] h_{2}=99.32\right.$ [KJKg]

Therefore the mass flow is:

$$
m=0.002046[K g s]
$$

With this mass flow the amount of power required in the compressor can be determined,

$$
W_{\text {in }}=0.0702[K W]
$$

The closest compressor to this value is 0.093 [KW] (1/8 HP). An Embraco compressor of this power is then chosen.

For the condenser, an analysis similar to that carried out for the evaporator can be made, only considering that, the function of the condenser is to reject heat $\left(\mathrm{Q}_{\mathrm{H}}\right)$ towards the surrounding environment and that, equally, the conservation of the mass must be fulfilled, which yields:

$$
Q_{H}=m\left(h_{2}-h_{3}\right)
$$

The condenser area necessary can be calculated (6) where, $h$ is the transfer coefficient between the condenser and the environment and the temperatures correspond to the ambient and the coolant. [7]

$$
\begin{aligned}
& h=76.5\left[\mathrm{~W} / \mathrm{m}^{2} \mathrm{~K}\right] \\
& A_{\text {cond }}=0.32[\mathrm{~m} 2]
\end{aligned}
$$

The heat flow in the condenser is:

$$
Q_{H}=0.469[K J s]
$$

The capillary tube diameter used to perform the expansion was chosen as recommended by the compressor manufacturer: 0.31 [mm], length: 3.1 [m]. [4]

To remove dirt and metal particles present, a 1/4" DX-25 weldable universal dryer filter (with silica gel particles) will be installed as it is a very commercial alternative.

The suction and discharge pipes are in flexible copper and the diameters are defined according to the compressor that had been previously selected. Suction and discharge diameters are 5/16" and $1 / 4$ " respectively.

For the insulation, a layer of Thermolon was used, which has a metallic face, which allows to reject the radiant heat by reflection, the layer is $20 \mathrm{~mm}$ thick, in addition, this insulation is waterproof, highly commercial and easy to handle.

\section{Assemblies and adaptations}

The cooling system was installed in a conventional manner and the pipe was isolated with rubatex and the evaporator with Thermolon.

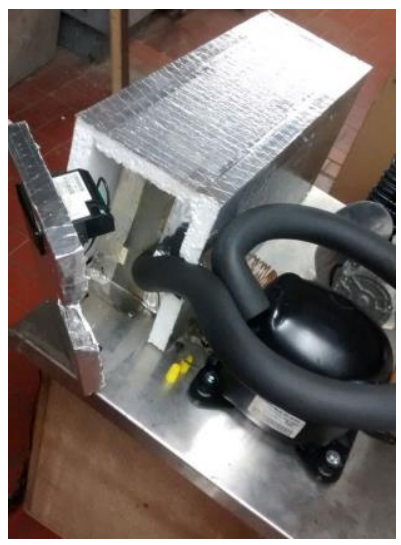

Fig. 1. Pipe and evaporator insulation

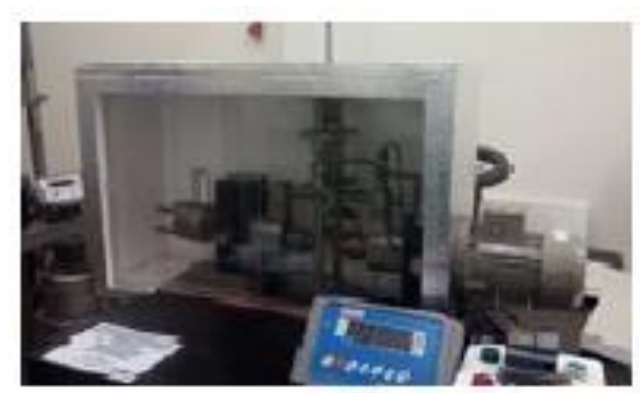

a) 


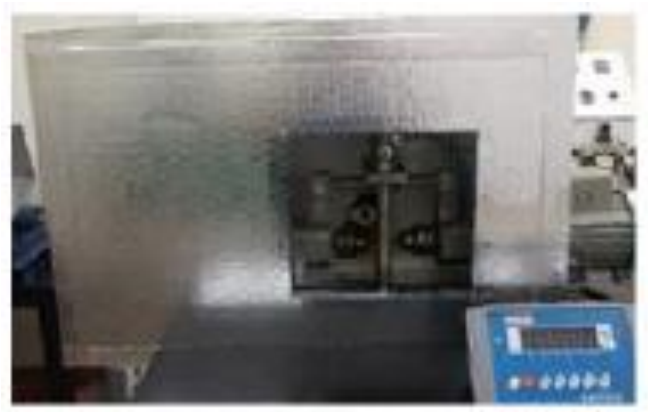

b)

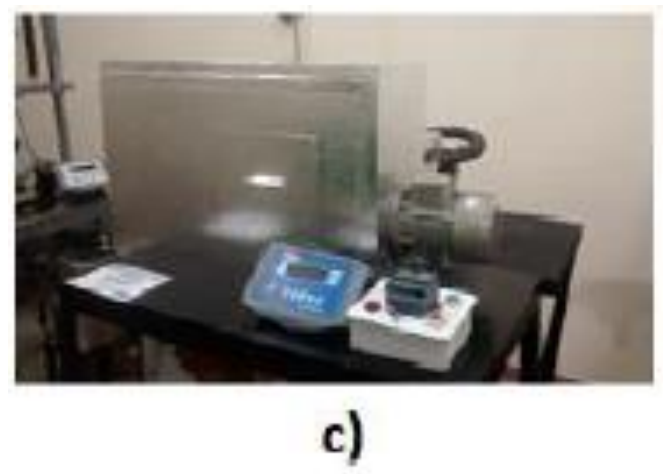

Fig. 2. In the same way, to reduce losses, a coating to make it was decided on the existing acrylic layer, also using $20 \mathrm{~mm}$ Thermolon. The front part is shown in Fig. 2a, while a window left as a viewfinder is shown in Fig. 2b, to monitor operation during the test and, finally, in Fig. 2c, the cooled chamber is completely covered.

Finally, insulation was made in the pipelines and pipes, with the reducing losses aim and also covering the system and improving its aesthetic appearance.
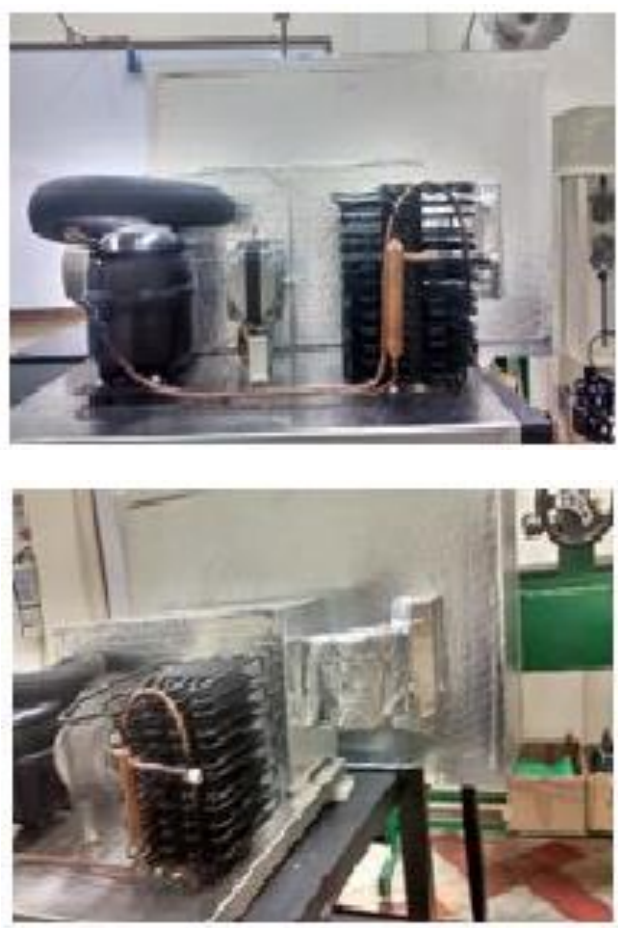

Fig. 2. General view of the insulations.

\section{RESULTS}

The system was started and monitoring pressures high and low, as well as the current demanded by the system. The measured data is found in Table I. On the other hand, Fig. 3 shows current measurements images and the pressure gauges connected at the high and low pressure system points.

TABLE I.

Operational VARIABLES Right AFTER STARTING

\begin{tabular}{lc}
\hline \hline \multicolumn{1}{c}{ Variable } & Value \\
\hline Low pressure & $14 \mathrm{psi}$ \\
High pressure & $125 \mathrm{psi}$ \\
Chamber temperature & $24.9^{\circ} \mathrm{C}$ \\
Electric current & $1.4 \mathrm{~A}$ \\
Electric power & $175 \mathrm{~W}$ \\
\hline \hline
\end{tabular}

As expected, the system has a transitory stage that causes the pressures and current demand to fluctuate, this happens while the system overcomes the thermal inertia and, for this case, it was observed that after 15 minutes of operation both pressures and current stabilized.

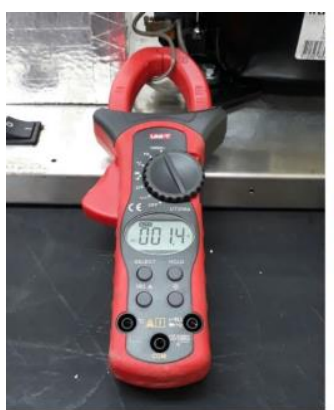

a)

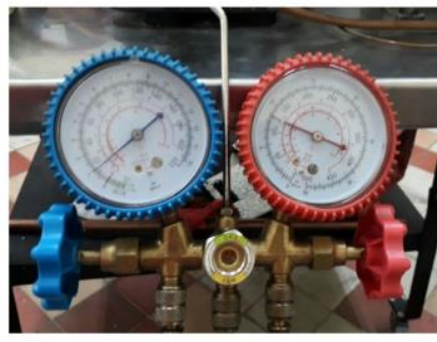

b)
Fig. 3. Startup measurements

Table II shows the operation variables after 2 hours after the system was started. Similarly, in Fig. 4, images taken at the same time are appreciated. Finally, Fig. 5 shows the cooling system operating at a temperature of $-5.2^{\circ} \mathrm{C}$, which falls within the range proposed to be reached in this work, which was between 0 and $-6{ }^{\circ} \mathrm{C}$.

TABLE II

OPERATION VARIABLES AT 2 HOURS OF COMMISSIONING.

\begin{tabular}{lc}
\hline \hline \multicolumn{1}{c}{ Variable } & Value \\
\hline Low pressure & $12 \mathrm{psi}$ \\
High pressure & $135 \mathrm{psi}$ \\
Chamber temperature & $0.1^{\circ} \mathrm{C}$ \\
Electric current & $1.2 \mathrm{~A}$ \\
Electric power & $150 \mathrm{~W}$ \\
\hline \hline
\end{tabular}




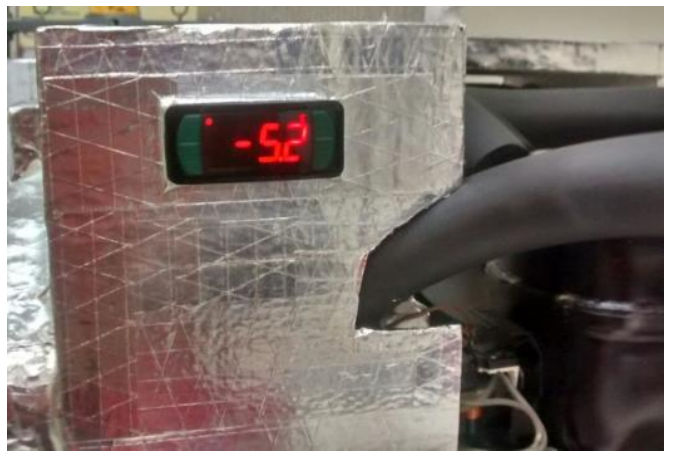

Fig. 4. Proposed temperature reached.

Since the compressor has a slightly higher power than necessary, the compression capacity is not limiting for cooling. However, uncontrollable conditions, such as environmental factors, do represent a system limitation, especially when these conditions can vary dramatically in a matter of hours during the same day. Therefore, sufficient time must be given to the system to stabilize the temperature and thus ensure repetitive conditions during the performance of low temperature fatigue tests.

Once the operational temperature corresponding to the present work objective was reached, three fatigue tests were performed to validate the system in a functional way. All tests were performed under identical test parameters, which are listed in Table III. On the other hand, in Fig. 6 the three specimens used in the equipment functional validation are shown.

TABLE III.

VALIDATION TEST PARAMETERS

\begin{tabular}{lc}
\hline \hline \multicolumn{1}{c}{ Variable } & Value \\
\hline Load & $10 \mathrm{Kg}$ \\
Temperature & $-2^{\circ} \mathrm{C}$ \\
Material & SAE AISI 1020 \\
Repetitions & 3 \\
\hline \hline
\end{tabular}

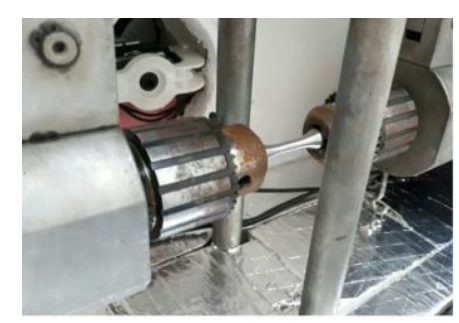

a)

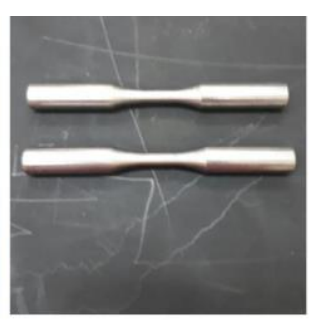

b)
Fig. 5. Test specimens a) mounted on machine b) unassembled

When a test is done for the first time, the specimen must be mounted, the refrigerated space closed and then the cooling system started. Because the entire system is at room temperature, the thermal inertia is quite large, which makes the time to reach the target temperature quite large.

Once the system reaches its target temperature, the test can be started and, after the first test, the refrigerated space is opened, the test specimen is disassembled and the new specimen is mounted. In this case, the thermal inertia is significantly lower, but nonetheless, it leads to the removal of a heat amount that is less than initially removed.

TABLE IV.

PRE-TEST TIMES

\begin{tabular}{lcc}
\hline \hline & Operation & Duration \\
\hline Mounting & 5 horas \\
Change & 1.5 horas \\
\hline \hline
\end{tabular}

This second removed heat amount can be determined at the initially removed heat amount, that is, by (3). For this, it is necessary to know at what temperature it is reached during the period in which the specimen is changed; this value was able to register $8^{\circ} \mathrm{C}$ values. Therefore, it has:

$$
\Delta T=8-(-6)=14^{\circ} \mathrm{C}
$$

Making the same consideration of $5 \%$ of the removed heat to represent the exchange with the environment, using (3), the removed heat in the second stage is:

$$
Q_{2}=63.87[K J]
$$

Having the removed heat values and the times required for this purpose, it can determine the power value used to heat remove, so, for the first test have, on average:

$$
W=\frac{155.1 K W}{5 h * 3600 s}=8.7[W]
$$

While, for successive tests, on average there is a power of:

$$
W_{2}=\frac{63.87 K W}{1.5 h * 3600 s}=11.82[W]
$$

\section{CONCLUSIONS}

The necessary adjustments were made in the rotary fatigue test bench, so that it was possible to reach temperatures of up to $5.2^{\circ} \mathrm{C}$ below zero. This temperature value is within the range proposed to reach the present work objectives, which was from $0^{\circ} \mathrm{C}$ to $-6^{\circ} \mathrm{C}$. This means that the final value reached was $13 \%$ above the minimum temperature value proposed in the target range.

It was determined that the removed heat for testing once a first test is performed can be up to $43 \%$ less than the initial heat. This makes sense if thermal inertia is considered to be significantly less when repetitions are made since much of this inertia is removed at the beginning.

It can be seen from the compressor performance table that the compressor capacity does not represent a system cooling capacity limitation. However, environmental conditions and their drastic changes may be, but not to the point of preventing reaching the objective ranges of this work. This results in future system operating parameters optimization, so that it can 
guarantee the desired temperature conditions in shorter, welldefined times and in better repetitive conditions.

\section{REFERENCES}

[1] S. Quintana, "Diseño de un banco de pruebas de fatiga en flexión rotativa para evaluar el comportamiento a cargas cíclicas," Sci. Tech., vol. 23, no. 3, pp. 324-333, 2018, DOI: 10.22517/23447214.16891.

[2] A. J. DE SANTIS, Análisis de fallos en sistemas aeronáuticos. Ediciones Paraninfo, S.A., 2015

[3] K. Budynas, R., \& Nisbett, Diseño en ingeniería mecánica de Shigley., 8th ed. Mexico: MaGraw Hill, 2008.

[4] Y. C. y M. Boles, TERMODINÁNICA, 7th ed. McGraw Hill, 2012.

[5] Gasservei, "Refrigerantes," Gasservei, 2019. https://www.gasservei.com/productos/refrigerantes/refrigeranteshfc/gasficha/r-134a/ (accessed Oct. 15, 2017).

[6] MatWeb, "MatWeb," 2017. http://www.matweb.com/index.aspx (accessed Oct. 15, 2017).

[7] S. Rodriguez, A. M., \& Rueda, "Diseño para la construcción y prototipado de una cámara climática para la calibración de termo higrómetros para la fundación oftalmológica de Santander-clínica foscal," Universidad Industrial de Santander, 2016.

[8] M. Dincer, I., \& Kanoglu, Refrigeration systems and applications, 2nd ed. Wiley, 2010.

[9] Y. C. y A. Ghajar, Transferencia de calor y masa. Mexico: McGraw Hill, 2011.

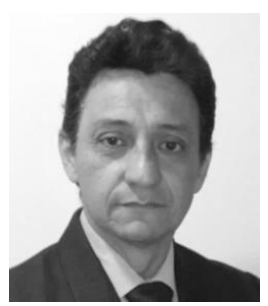

Carlos Gerardo Cárdenas Arias, was born in Bucaramanga, Santander, Colombia. Graduated in mechanical enginnering from the Universidad Industrial de Santander. Specialist in university teaching and magister in education from the Universidad Cooperativa de Colombia. Master's studies in materials engineering and candidate for $\mathrm{PhD}$ in materials and sustainable process engineering at the Universidad del País Vasco, Bilbao, Spain.

Full-time professor at the Unidades Tecnológicas de Santander, in electromechanical engineering, in the design area. Associate researcher attached to the DIMAT research group, in lines of design and materials.

ORCID: https://orcid.org/0000-0003-4447-5828

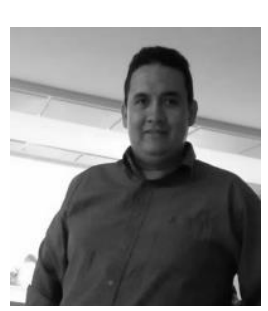

Sandoval R. Camilo Leonardo is an Electronic Engineer, Master in Electronic Engineering and Ph.D (c) in Electronics and Telecommunications from the Universidad del Pais Vasco. Leader of the research group in energy systems, automation and control GISEAC of the (Unidades Tecnológicas de Santander) UTS. His areas of interest are: automatic control, signal processing and pattern recognition, applied to the analysis of materials and structures, and biomedical engineering. With 14 publications, more than 100 directed engineering degree works and more than 30 participations as a speaker in scientific and academic events. Consultant specialized in automatic control systems, participation in various technological development and innovation projects. He is recognized as an Associate Researcher (I) according to the Ministry of Science, Technology and Innovation of the Republic of Colombia, from 2018 to the present.

ORCID: https://orcid.org/0000-0001-8584-0137

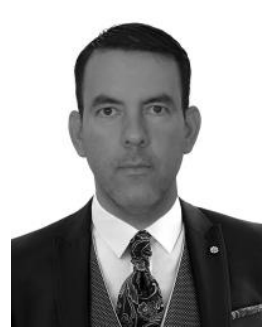

Arly Darío Rincón Quintero was born in Aguachica, Cesar, Colombia in 1982. $\mathrm{He}$ received the degree in mechanical engineering from Francisco de Paula Santander University, Colombia, in 2005 and the degree Master in Energy Efficiency and Sustainability from the University of the Basque Country UPV/EHU, Bilbao, España, in 2013. He is currently pursuing the Ph.D. degree in Energy efficiency and sustainability in engineering and architecture with Basque Country UPV/EHU, Bilbao, España.

$\mathrm{He}$ is a senior researcher before MinCiencias, Colombia associate professor at the Unidades Tecnologicas de Santander, in the Faculty of Natural Sciences and Engineering.

ORCID: https://orcid.org/0000-0002-4479-5613 


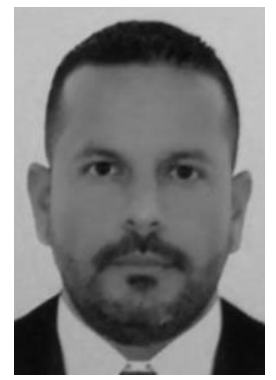

Pablo David Diaz Melo, was born in Bucaramanga, Santander, Colombia in 1982. He began his studies of electromechanical technology at the Unidades Tecnologicas de Santander. He obtained his electromechanical engineering degree from the Universidad Antonio Nariño and his specialist degree in energy resource management from the Universidad Autónoma de Bucaramanga. He is currently linked to the automotive industry sector with more than 15 years of experience.

ORCID: https://orcid.org/0000-0003-4228-0250 